\title{
STRUCTURE SHIFT IN INDONESIAN - ENGLISH TRANSLATION
}

\author{
I Ketut Subagia \\ Warmadewa University \\ subagia35@yahoo.com \\ I Made Astu Mahayana \\ Warmadewa University \\ astumahayana@gmail.com
}

\begin{abstract}
Structure shift is one of the problems in translations. This problem is important to be dealt with because it is the most frequent category occurring at all rank in translation. Besides, in grammar structure shift can occur at all ranks. The discussion about structure shift only covers structure shift in phrase, clause, and sentence level. This research used the translation theory proposed by J.C. Catford (1965). He states that shift is departure from formal correspondence in the process of going form the SL to the TL. He also states that there are two kinds of shift in translating, namely level-shift and category-shift. Category shift means the change of formal structure of the SL, in process of translating into the TL. The data source is taken from four bilingual folklores. Data collecting used observation method and descriptive method was employed in analyzing the data. The findings show that in phrase level structure shift found only in noun and adjective phrase. The shifts in noun phrase are: $\mathrm{H}$ PostM PostM into PreM PreM H, H PostM into PreM H, and PreM H PostM Post M, into PreM PreM PreM H. In adjective phrase structure shift is found only one i.e. PreM H into H PostM. The structure shift in clause level is: SC into SVC, SV into SVA, and SV into SVO. In sentence level structure shift occur from simple sentence in SL into simple sentence in TL, simple sentence in SL into complex sentence in TL, complex sentence in SL into simple sentence in TL, and complec sentence in SL into complex sentence in TL.
\end{abstract}

Keywords: structure shifts, sentence, head, modifier

\section{INTRODUCTION}

Translation plays an important role in academic activities. It can be shown that translation is generally used as a bridge to understand the knowledge contained in the source references. As we know most of the references that are available in courses or universities are written in English. But on the other hand most of the students are not able to do the reading well in English so that they cannot get the knowledge in the references.

The research about shift have been done by Aisyah (2015), entitled The Shift and Equivalence in the English Translation from Indonesian Noun Phrases in the Poem 'Pantun Terang Buln di Midwest' by Taufik Ismail. She talks about all types of shift (Aisyah, 2015). The other research of shift have been done by Herman. He limited analysis to unit shifts in the high level to lower level and low level to higher level, but this research is only focused on structure shift (Herman, 2017). 
Besides, in academic activities translation is also important in many fields of life such as trade, tourism, court, and electronic. Therefore, translation is not only a subject of linguists, professional and amateur translators and languageteachers, but also of electronic engineers, mathematicians, and other professions.

By translation we mean a kind of transferring of meaning from a source language into receptor language. Translation is basically a change of form. In translation, the form of the source language is replaced by that of the receptor (target) language (Larson, 1984: 3). However, the process of translating is not as easy as how the words read, it has many factors involved. As Larson states translation, then, consists of studying the lexicon, grammatical structure, communication situation, and cultural context of the source of language text.

Nababan differentiates kinds of translation. He states that there are several kinds of translation, such as word for word translation, free translation, literal translation, dynamic translation, pragmatic translation, aesthetic-poetic translation, ethnographic translation, linguistic translation communicative translation and semantic translation (Nababan, 2008: 30).

Nida states there are some aspects to be mastered in the process of translating. A good translator should master the field of the text, the source language, the receptor language and the theory of translation. But more than this, a translator should also know the culture of both languages because translation also involves culture. Although we have got these principles, we cannot transfer the total meaning of the source language into receptor language since no languages in the world are identical. There must be what we call loss and gain in our translation and there must be problems as well (in Sakri, 1985: 1).

If we pay attention to the idea given above, considering that no languages in the world are identical, in the process of translating we rarely have parallel structures of the two languages involved. And what is mainly focused in the process of translating is transferring the message of the source language into receptor language. This research tries to find the closest equivalent between the source language and the receptor language. Perhaps by this concept we often find unparalleled structure, even we often find structural shift.

Assuming that English and Indonesian are not identical, although in some cases they have the same structure, since every type of structure carries different meaning, in the process of translating English text into Indonesian there must be unparalleled correspondences of clause structures in it. For example, an English sentence like She wore a hat, which has the type of SVO, can be translated into "Dia bertopi" that has the SV type. In this example we can see a change of simple clause type (from SVO to SV).

With the explanation just outlined, the problem which is important enough to be talked about this research, is structure shift in Indonesian-English translation. Since, the structure shift can occur in the sentence, clause, phrase, word, and morpheme, the problem is too wide to be dealt with in this research. So the problem of this paper is to analyze the kind of the structure shift found in phrase, clause, and sentence.

\section{METHODS}

There are three methods which are used in this research. They are determining the data source, collecting the data, and analyzing the data. The data source were taken from four bilingual folklores, they are Dongeng Danau Toba 
(The Legend of Lake Toba), Asal Mula Selat Bali (The History of Bali Strait), Kakua dan Kekele (Kakuwa and Kekele), and Nyai Bungsu Rangrang.

The method that is used in collecting the data is observation method. Each use of the structure shifts in those folklores are read and written down in a book that has been prepared before. After the data have been identified based on the types of phrase, clause, and sentence structure, they are analyzed based on theory adopted. In this case, it uses descriptive method, that is, by describing what kind of phrase, clause, and sentence type shift occur, and the description of the shifts are supported by giving examples that are taken from the data. Discussion, comment, or explanations after the example are also presented.

\section{DISCUSSIONS}

Margono, in his Essential of Theory and Practice of Translation proposed a diagram of translation process: He explained that the processes of analyzing a translation may consist of: (a) Analyzing grammatical relationship between constituent parts, (b) Identify the meanings of the semantic units, and (c) Finding the connotative meanings of the grammatical structures and semantic units (Margono, 1999: 4).

As has been mentioned previously, this paper will analyze structure shift in Indonesian-English translation. The analysis covers structure shift at the phrase, clause, and sentence level. For more detail explanations, each structure is explained in the following subchapter.

\section{Structure Shift at Phrase Level}

Catford states that structure shifts occur when translators resort to arranging lower rank units (nouns, verbs, adjectives, adverbs, etc.) that form a larger unit (clause and sentence) differently (Catford, 1965: 77). After observing the data, it was found that mostly the types of the Indonesian phrase structure were typically transferred into English. For example: Dia tahu anaknya telah mencuri genta dan ... is transferred into English He knew that Manik Angkeran had stolen his magic bell and ... (Haryadi, 2002: 20). The Indonesian phrase telah mencuri which belongs to aux $M V$ type was simply transferred into English had stolen which also belong to aux MV type. So in this example we can see the types of phrase structural both source language and target language are the same. Another example showing no movement of type of phrase structure in target language is in the following sentence: . . untuk bersemadi di kaki gunung itu, was translated into . . . for meditation at the foot of the mountain (Haryadi, 2002: 10). Indonesian phrase di kaki gunung itu, which belongs to P PC type was simply translated into at the foot of the mountain, which also belongs to P PC type.

Ghani Johan states that the most dominant element of sentence is a noun or noun phrase that can occupy the subject, object, complement, or as adverbial which part of preposition phrase. There are three elements of noun phrase, they are: the head, the pre-modifiers, and the post modifiers (Leech, 1986: 61-62). Although the types of the Indonesian phrase structure mostly have the same type in their translations, some of them have different ones. It was found that different type of phrase structure in the source language is variously shifted in the target language. What is meant here is that beside parallel phrase structure, phrase structure types of source language may also have different types in their translation. The specific example about it is given as follows. 
Vol. 2, No. 1, Januari 2018, 49

Available Online at https://ejournal.warmadewa.ac.id/index.php/kulturistik

DOI: dx.doi.org/10.22225/kulturistik.2.1.491

1) SL : $\frac{\mathrm{Ikan}}{\mathrm{H}} \frac{\text { mas }}{\text { Post } \mathrm{M}} \frac{\text { yang besar itu muncul ke permukaan }}{\text { Post } \mathrm{M}}$

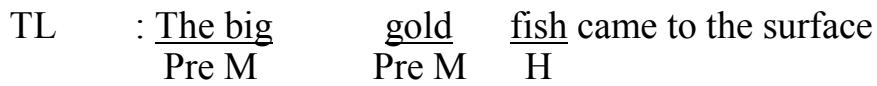

(Haryadi, 2001)

2) SL : Setelah ikan itu cukup besar

TL : When it was big enough

(Haryadi, 2001)

$\mathrm{H} \frac{\mathrm{est} \mathrm{M}}{\text { Pos }}$

3) SL : Memetik buah wuni dengan mudah

TL : Picking wuni fruits easily

(Oeban, 2001)

$$
\text { Pre } \mathrm{M} \frac{\mathrm{H}}{\mathrm{H}}
$$

4)

$$
\begin{aligned}
& \text { SL : Anak itu mendapat seekor ikan mas kecil } \\
& \text { TL : The boygot a small gold fish } \\
& \text { (Haryadi, 2001) } \\
& \text { PreM PreM PreM } \mathrm{H}
\end{aligned}
$$

Phrase in example number (1) is ikan mas yang besar itu was translated into the big gold fish. The phrase belongs to noun phrase. Therefore, it can be analyzed into ikan (H), mas (PostM), and yang besar itu (PostM). So, its structure is $\mathrm{H}$ PostM PostM. Its translation can be analyzed into the big (PreM), gold (PreM) and fish $(\mathrm{H})$. So, its structure is PreM PreM H. Based on the analysis above it can be said that there is phrase structure shift in example number (1). In the source language, the modifiers follow the head, whereas in target language the modifiers precede the head.

Phrase structure shift can also be found in example number (2). The phrase is cukup besar. It belongs to adjective phrase (Ajp) because the head of the phrase is an adjective. This phrase can be analyzed into cukup (PreM) and besar $(\mathrm{H})$. But it is different structure of phrase in the target language. The $\mathrm{H}$ precedes the modifiers. The translation of cukup besar is big $(\mathrm{H})$ and enough (PostM). Based on the analysis above, it can be said that there is phrase structure shift in example number (2). The H of the phrase is SL follows the modifier but the phrase in TL, the $\mathrm{H}$ precedes the modifier.

The phrase in example number (3) is buah wuni that is translated into wuni fruits. The phrase belongs to noun phrase because the head of that phrase is noun. Phrase buah wuni can be described into buah $(\mathrm{H})$ and wuni (PostM). So, its structure is H PostM. But it is different structure of the phrase in the target language. Completely, wuni fruits can be analyzed into wuni (PosM) and fruits $(\mathrm{H})$. Based on the analysis above, it can be concluded that it is found phrase structure shift in example number (3). In the SL modifier follows the H, but in the TL modifier precede the $\mathrm{H}$.

Phrase structure shift is also found in example number (4). The difference 
of this example to another is in this example is found more modifiers. For getting more detail explanation, the phrase in example number (4) is analyzed as follows. Phrase seekor ikan mas kecil belongs to noun phrase. It can be analysed into seekor (PreM), ikan (H), mas (PostM), and kecil (PostM). Therefore, it can be said that the structure of the phrase is SL is PreM H PostM PostM. The translation of that phrase is a small gold fish that can be described into a (PreM), small (PreM), gold (PreM), and fish (H). So, its structure is PreM PreM PreM H. Based on this analysis, it can be told that modifiers of phrase in SL precede and follow the $\mathrm{H}$ or in other words, the $\mathrm{H}$ of phrase in SL is preceded by a modifier and followed by two modifiers. However, all modifiers of the phrase in TL precede the $\mathrm{H}$.

\section{Structure Shift at the Clause Level}

The clause structure shift will occur when the source language and target language have formal correspondence in translation. Indonesian-English translation has formal correspondence. Therefore, there are many clause structure shifts in its translation.

Clause structure shift can be known when there are changes of clause structure from source language into target language. Ramlan states that Syntax is the science that studies the relationship between words or phrases or clauses or sentences that one with a word or phrase (clause or another sentence or specifically learn the intricacies of the phrase, clause, sentence and discourse (Ramlan, 1982: 21). Besides, Quirk (1973: 12) states that a sentence may alternatively be seen as comprising five units called elements of sentence structure: subject, verb, complement, object, and adverbial (Quirk, 1973: 12). It can be seen in examples below. Examples:

1) SL : Sebelum matahari terbit, pak Waluh berangkat

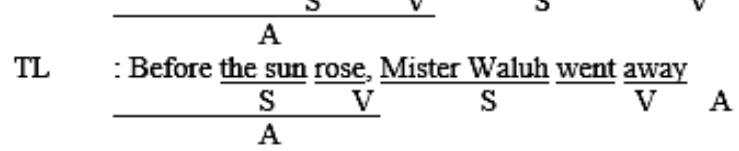

(Oeban, 2001)

2) SL : Setelah ikan itu cukup besar, dia memindahkan nya ke kolam di belakang gubuknya

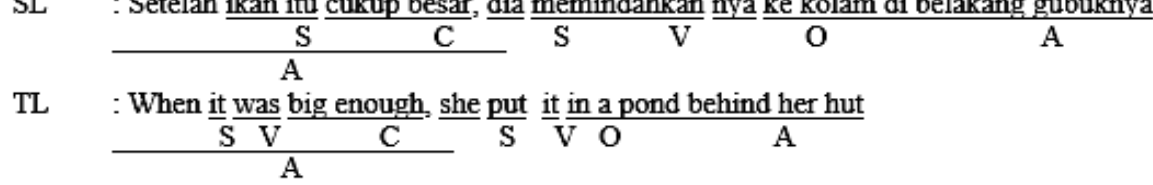

(Haryadi, 2001)

3) SL : $\frac{\text { Jangan siksa dia }}{\mathrm{V}} \frac{\text { aniingmu }}{\mathrm{S}} \frac{\text { tidak berdosa! }}{\mathrm{V}}$

TL : $\frac{\text { Don't beat him }}{\mathrm{V}} \frac{\text { your dog did nothing wrong! }}{\mathrm{S}} \frac{\mathrm{O}}{\mathrm{V}}$

(Singo, 2001)

Sentence in SL in example number (1) belongs to complex sentence because it is formed by two clauses. They are sebelum matahari terbit and Pak Waluh berangkat. Sebelum matahari terbit belongs to dependent clause and Pak Waluh berangkat belongs to independent clause. 
Sentence in TL also belongs to complex sentence because it is formed by two clauses. Before the sun rose belongs to dependent clause and Mister Waluh away went awaybelongs to independent clause.

In this example, clause structure shift can be found in independent clause. Independent clause in SL can be analyzed into the element of S (Pak Waluh) and V (berangkat). So, its structure is SV whereas, the independent clause in TL can be described into element of S (Mister Waluh), V (went), and A (away). So its structure is SVA. Based on the analysis above, it can be said that there is clause structure shift in example number (1) i.e. from SV into SVA.

Clause structure shift can be found also in example number (2). Sentence in SL and in TL both belong to complex sentences because they are formed by two clauses each. Sentence in SL is formed by setelah ikan itu cukup besar which belongs to dependent clause and dia memindahkannya ke kolam di belakang gubuknya which belongs to independent clause while the sentence in TL is formed by when it was big enough which belongs to dependent clause and she put it in pond behind her hut, which belongs to independent clause.

In this example clause structure shift is found in dependent clause. Clearly, dependent clause in SL can be analyzed into the exponent of ikan itu (S) and cukup besar (C). So, its structure is SC. Whereas, dependent clause in TL can be described into the exponent of it (S), was (V), and big enough (C). So its structure is SVC. Based on analysis above, it can be said that there is clause structure shift in example number (2) i.e. from SC into SVC.

Clause structure shift is also found in example number (3). Both sentences in example no (3) belong to compound sentences. It means that each sentence consist of more than one clause. Compound sentence in SL is formed by two clauses. They are jangan siksa dia which belongs to independent clause and anjingmu tidak berdosa which also belongs to independent clause. While, compound sentence in TL is formed also by two clauses. They are don't beat him which belongs to independent clause and your dog did nothing wrong which also belongs to independent clause.

Clause structure shift can be found in independent clause number second i.e. anjingmu tidak berdosa and it is translated into your dog did nothing wrong. Clearly, each clause can be analyzed into anjingmu (S) tidak berdosa (V). It means the structure of this clause is SV while the structure of the clause in TL is SVO. It can be segmented as the element of S (your dog), V (did), and O (nothing wrong). Based on the analysis above, it can be said that clause structure shift from $\mathrm{SV}$ into SVO is found in example number (3).

\section{Structure Shift at Sentence Level}

Besides occurring in the phrase and the clauses level, structure shift can also be found at the sentence level. The shift at the sentence level occurs when both source language and target language have formal correspondence in the sentence level. The sentence of Indonesian-English translation has formal correspondence. Therefore, there are many sentence structure shifts in its translation.

For determining sentence structure shift, it can be seen from two aspects. First, it can be seen from the difference of elements of the source language and the target language. Second, it can be noticed from the sequences of the elements that build up both the source and the target language sentence structure.

Based on these aspects, the sentence structure shift analyzed is the simple 
sentence and the complex sentence. The structure shift of the simple sentences in the source language examined is the structure shift of the simple sentences into the simple sentences and into the complex sentences in target language. Besides, the structure shift of complex sentences in the source language examined is the structure shift of the complex sentence into the simple sentences and into the complex sentences in TL. For getting more detail illustration, let us see explanation below.

\section{From Simple Sentence in SL into Simple Sentence in TL}

Some data show that structure shift occurs from the simple sentence in SL into the simple in TL. The data cover the different elements and the different sequence of the elements of the sentences in both SL and TL. Examples and explanations below make this point clearer. Examples:

1)

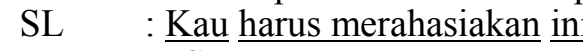

TL : You must keep this as a secret

(Haryadi, 2002)

$\frac{\text { You }}{\mathrm{S}} \frac{\text { must keep }}{\mathrm{V}} \frac{\text { this }}{\mathrm{O}} \frac{\text { as a secret }}{\mathrm{A}}$

2) SL : Sekarang anak itu telah remaja

TL : Now the boy has become a teenager

(Singo, 2001)
A

3)

$\frac{\text { Dia sangat lapar }}{\mathrm{S}} \frac{\mathrm{C}}{\mathrm{C}}$

TL $: \frac{\mathrm{He}}{\mathrm{S}} \frac{\mathrm{was}}{\mathrm{V}} \frac{\text { very hungry }}{\mathrm{C}}$

(Singo, 2001)

4) SL : Perlakuan sang istri sungguh tidak menyenangkan

TL : The wife's treatment was $\frac{\text { so }}{\mathrm{V}} \frac{\text { unlpleasant }}{\mathrm{A}}$

(Oeban, 2001)

5) SL : Di dekat danau ada pohon wuni

TL : Near the lake there was a wuni tree

(Oeban, 2001)

6) SL : Dia berhutang untuk berjudi

$\mathrm{S} \frac{\mathrm{V}}{\mathrm{A}}$

TL $: \frac{\mathrm{He}}{\mathrm{S}} \frac{\text { borrowed }}{\mathrm{V}} \frac{\text { some money for gambling }}{\mathrm{O}}$

(Haryadi, 2002)

7) SL : $\frac{\text { Naga itu bermata ganas }}{\mathrm{S}}$

TL : The dragon had fierce eyes

(Haryadi, 2002)

$\mathrm{S} \quad \mathrm{V} \mathrm{O}$


The structure of the sentence in SL in example number (1) is SVO. It is into element of subject (kau), verb (harus merahasiakan), and object (ini) while the structure of sentence in TL is SVOA. That sentence can be analyzed into element of subject (you), verb (must sleep), object (this) and adverbial (as a secret). Based on analysis above, it can be said that there is different element of sentences in SL and in TL. It means that in example number (1) is found sentence structure shift. Both sentences in SL and in TL belong to simple sentence because it consists of only one clause.

Example number (2) also proves that there is sentence structure shift in those sentences. Clearly, sentence in SL in example number (2) can be analyzed into the element of adverbial (sekarang), subject (anak itu), and complement (telah remaja). While, the sentence in TL is into the element of adverbial (now), subject (the boy), verb (has become), and complement (a teenager). Based on this analysis, the structure of sentence in SL sentence in SL is ASC and the structure of sentence in TL is ASVC. It menas that sentence in SL and sentence in TL has different element. Both sentences in TL and in SL belong to simple sentence because it consists of only one clause.

Sentence structure shift is also found in example number (3). The structure of sentence in SL in example number (3) is SC. The subject is filled by dia and complement is filled by sangat lapar while the structure of sentence in TL is SVC. It is into the element of subject is filled by he, verb is was, and complement is very hungry. This analysis proves that sentence in SL and sentence in TL have different structure and belong to simple sentence. It means that there is structure shift in example number (3).

The different element of simple sentence can also be found in example number (4). The element of subject of the sentence in SL is filled by perlakuan sang istri, adverbial is filled by sungguh, and verb is filled by tidak menyenangkan. It means the structure of the sentence in SL is SAV. The different element of the sentence in TL is shown by the element of subject is filled by was, adverbial is filled by so, and complement is filled by unpleasant. It means the structure of the sentence in TL is SVAC. The different of the structure of the sentences in both SL and TL prove that in example number (4) is found sentence structure shift.

Sentence structure shift that is caused by the different element is also found in example number (5). Sentence in SL in example number (5) can be described into the element of A (di dekat danau), V (ada), S (pohon wuni). It means the structure of this sentence is AVS while the structure of sentence in TL is ASVC. It is into the element of A (near the lake), S (there), $\mathrm{V}$ (was), and $\mathrm{C}$ (a wuni tree). This analysis proves that sentence in SL and sentence in TL have different structure. Therefore, there is sentence structure shift in example number (5). The sentences in both SL and TL belong to simple sentence because they are formed by only one clause each.

Structure shift from simple sentence in SL into simple sentence in TL is also found in example number (6). In this example, the shift is also caused by the different elements of those sentences. Sentence in SL can be analyzed into the element of S (dia), V (berhutang), and A (untuk berjudi). So, its structure is SVA while the structure of sentence in TL is SVOA. It is into the element of S (he), V (borrowed), $\mathrm{O}$ (some money), and $\mathrm{A}$ (for gambling). This analysis proves that there is sentence structure shift in example number (6). Both sentences belong to 
simple sentence because each sentence consists of only one clause.

In example number (7) is also found different element between sentence in SL and sentence in TL. These sentences also belong to simple sentence because each sentence is only formed by one clause. The shift of these sentences is proved by analysis below. The structure of simple sentence in SL in example no (7) is SVC. It is into the exponent of naga itu (S), bermata (V), and ganas (C). The structure of this translation is SVO. It is into the exponent of the dragon (S), had $(\mathrm{V})$, and fierce eyes $(\mathrm{O})$. This analysis proves that there is simple structure shift in example number (7).

The different way for seeing sentence structure shift in simple sentence in both SL and TL is by seeing the different sequence of elements carried by those two different sentences. The examples and explanations below make this point clearer. Examples:

1)

$$
\begin{array}{ll}
\text { SL } & : \frac{\text { Sidi Mantra menunggu anaknya }}{\mathrm{S}} \frac{\text { dengan cemas }}{\mathrm{V}} \frac{\mathrm{a}}{\mathrm{A}} \\
\text { TL } & : \frac{\text { Worriedly, }}{\mathrm{A}}, \frac{\text { Sidi Mantra }}{\mathrm{S}} \frac{\text { waited }}{\mathrm{V}} \frac{\text { his son }}{\mathrm{O}}
\end{array}
$$

(Haryadi, 2002)

2) SL $: \frac{\text { Ikan yang malang itu langsung mati }}{\mathrm{S}}$

TL $: \frac{\text { The poor fish die }}{\mathrm{S}} \frac{\text { immediately }}{\mathrm{A}}$

(Haryadi, 2001)

The different sequence of the elements of the sentence in SL and TL is proved by the example number (1). The sentence in SL in example number (1) can be described into the element of subject (Sidi Mantra), verb (menunggu), object (anaknya), and adverbial (dengan cemas). It means that the structure of the sentence in SL is SVOA whereas the structure of the sentence in TL is ASVO. It is shown by the element of adverbial (worriedly), subject (Sidi Mantra), verb (waited), and object (his son). Based on the analysis above, it can be said that there is sentence structure shift in the example number (1) that is caused by the different elements of the sentence in both SL and TL. The sentences in both SL and TL in example number (1) belong to simple sentence because each of the sentences consists of one clause.

It is also found the sentence structure shift that is caused by the different sequence of the element of the simple sentence in SL and TL in example number (3). The sentence in SL in example number (3) can be described into the element of subject (ikan yang malang itu), adverbial (langsung), and verb (mati). It means that the structure of the sentence in SL is SAV whereas the structure of the sentence in TL is SVA. It is into the element of subject (the poor fish), verb (die), and adverbial (immediately). Sentences in both SL and TL belong to simple sentence.

\section{From Simple Sentence in SL into Complex Sentence in TL}

The following examples show that the structure shift also occurs from the simple sentence in source language to complex sentence in target language. Let us see the examples and explanation below. Examples: 
Vol. 2, No. 1, Januari 2018, 55

Available Online at https://ejournal.warmadewa.ac.id/index.php/kulturistik

DOI: dx.doi.org/10.22225/kulturistik.2.1.491

1)

\begin{tabular}{|c|c|c|}
\hline SL & $: \frac{\text { Mereka }}{\mathrm{S}}$ & $\frac{\text { makan }}{\mathrm{V}} \quad \frac{\text { buah }}{\mathrm{O}}$ \\
\hline TL & $\frac{\text { They }}{\mathrm{S}} \frac{\text { ate }}{\mathrm{V}}$ & $\frac{\text { the fruits }}{\mathrm{O}}$ \\
\hline
\end{tabular}

(Oeban, 2001) $\begin{array}{ll}\text { SL } & : \frac{\text { Pemuda itu }}{\mathrm{S}} \quad \frac{\text { menyesali }}{\mathrm{V}} \\ \text { TL } & \text { The young man }\end{array}$

TL : The young man

(Singo, 2001) $\frac{\text { sepuas-puasnya }}{\mathrm{A}}$

as much as they liked

A

The example number (1) shows us that there is sentence structure shift from simple sentence in SL into complex sentence in TL. It is proved by the structure and the number of clause that form those sentences. Clearly, the sentence in SL can be analyzed into mereka (S), makan buah (O), and sepuaspuasnya (A). Thus, the structure of the sentence in SL in example number (1) is SVOA. This sentence belongs to simple sentence because it is formed by one clause. However, the structure of sentence in TL is SVOA (SV). It is into they $(\mathrm{S})$, ate $(\mathrm{V})$, the fruits $(\mathrm{O})$, and as much as they liked (A) that can be analyzed into they $(\mathrm{S})$ and liked $(\mathrm{V})$. This sentence belongs to complex sentence because it is formed by two clauses.

Sentence structure shift caused by the different kinds of the sentence can also be seen in example number (2). The sentence in SL Pemuda itu menyesali perbuatannya belongs to simple sentence because it is formed by only one clause. This sentence can be analyzed into pemuda itu (S), menyesali $(\mathrm{V})$, and perbuatannya $(\mathrm{O})$. So, its structure is SVO. The different kinds of the sentence in TL can be seen in this sentence i.e. the young man was sorry for what he did. This sentence belongs to complex sentence because it is formed by two clauses and marked by a Wh-word. Completely, it can be described into the young man (S), was $(\mathrm{V})$, sorry $(\mathrm{C})$, and for what he did (A) that can be analyzed into he (S) and $\operatorname{did}(\mathrm{V})$. Thus, the structure of this sentence is SVC A(SV).

\section{From Complex Sentence in SL into Simple Sentence in TL}

The sentence structure shift is also found from complex sentence in SL into simple sentence in TL. This shift can be seen in the following data. Examples:

1) SL : Dan sebelum matahari terbit, dia pergi ke arah timur

$$
\text { A }
$$

TL : And before the sunrise he went eastward

(Haryadi, 2002)

$$
\mathrm{A} \quad \mathrm{S} \frac{\mathrm{V}}{\mathrm{A}}
$$

2) SL : $\frac{\text { Sang Kakak }}{\mathrm{S}} \frac{\text { tak sabar, }}{\mathrm{C}} \frac{\text { pohon }}{\mathrm{S}} \frac{\text { segera dipanjat }}{\mathrm{A}}$

TL : Impatiently, the big brother begin to climb $\frac{\text { the tree }}{\mathrm{S}}$

(Oeban, 2001)

$$
\mathrm{A}, \frac{\mathrm{S}}{\mathrm{V}} \mathrm{O}
$$


From those examples, it can be seen that the structure shift occurs where the complex have different element with their translation to simple sentence in target language. In example number (1) the structure of complex sentence in SL is A (A S V), SVA. It is into element of adverbial (dan sebelum matahari terbit) that can be analyzed again into element of adverbial (sebelum), subject (matahari), and predicate (terbit), subject (dia), verb (pergi), and adverbial (kea rah timur) while the structure of the sentence in TL is A S V A. It is into element of adverbial (and before the sunrise), subject (he), verb (went), and adverbial (eastward). The sentence in SL belongs to complex sentence because it is formed by two clauses and one clause and the others are joined by subordination. And the sentence in TL is called simple sentence because it consists of only one clause. The different structure of the complex sentence in SL and of the simple sentence in TL proves that there is sentence structure shift in example number (1).

The example number (2) also shows that there is sentence structure shift from SL into TL. The sentence in SL can be analyzed into sang kakak (S), tak sabar (C), pohon (S), segera (A), and dipanjat (V). It means the structure of the sentence in SL is S C S A V. This sentence belongs to complex sentence because it consists of two clauses and is marked by comma. Whereas, the sentence in TL can be described into impatiently (A), the big brother $(\mathrm{S})$, begin to climb $(\mathrm{V})$, and the tree $(\mathrm{O})$. So, the structure of this sentence is ASVO. This sentence belongs to simple sentence because it consists of only one clause. The different structure of the complex sentence in SL into structure of simple sentence in TL proves that there is a sentence structure shift in example number (2).

\section{From Complex Sentences in SL into Complex Sentence in TL}

Some data also show that the structure shift occurs from complex sentence in SL into complex sentence in TL. Let us see the examples below. Examples:

1)

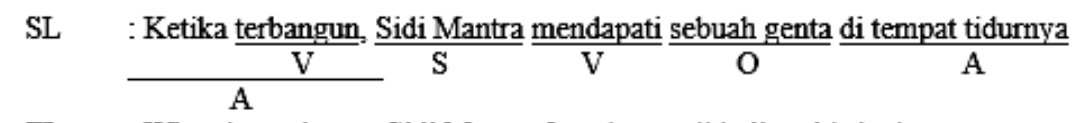

TL : When he woke up, Sidi Mantra found a small bell on his bed

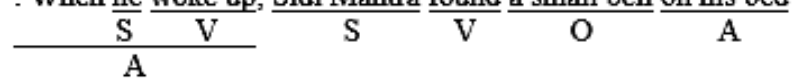

(Haryadi, 2002)

2) SL : Sebelum matahari terbit, Pak Waluh berangkat

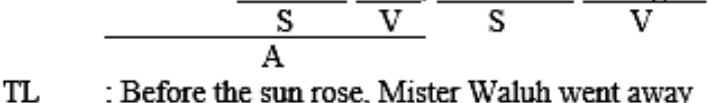

TL : Before the sun rose, $\frac{\text { Mister Waluh went away }}{\mathrm{S}} \frac{\mathrm{V}}{\mathrm{V}} \frac{\mathrm{V}}{\mathrm{A}}$

(Oeban, 2001)

3) SL : Suatu hari ketika ayahnya pergi lagi ke kaki Gunung Agung, diam-diam

$$
\text { A } \quad \frac{\text { S }}{\mathrm{A}}
$$

$\frac{\text { Manik Angkeran mengikuti nya }}{\mathrm{S}} \frac{\mathrm{O}}{\mathrm{O}}$

TL : One day when his father went again to the foot of Mount Agung, Manik Angkeran

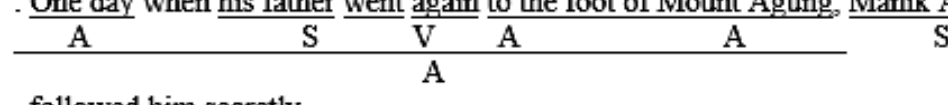

$\frac{\text { followed }}{\mathrm{V}} \frac{\text { him secretly }}{\mathrm{O}} \frac{\mathrm{A}}{\mathrm{A}}$

(Haryadi, 2002) 
Those examples above show us that the structure shift in complex sentence is caused by the different elements and the different sequence of the elements of the structure in both SL and TL. The structure shift that is caused by the different element can be seen in example number (1) and number (2). The sentence that is caused by the different sequence of the elements can be seen in example number (3).

In example number (1), complex sentence in SL can be analyzed into the exponent ketika terbangun (A), Sidi Mantra (S), mendapati (V), sebuah genta (O), and di tempat tidurnya (A). The element of (A) ketika terbangun can be described into terbangun (V). So, the structure of this sentence is A (V) SVOA. This sentence belongs to complex sentence because it consists of two clauses and is marked by a conjunction. The sentence in TL can be described into the exponent when he woke up (A), Sidi Mantra (S), found (V), a small bell (O), and on his bed (A). The element of (A) when he woke up can be described again into he (S) and woke up (V). So, its structure is A (SV) SVOA. This sentence belongs to complex sentence because it consists of two clauses. One clause and the others are joined by a conjunction. This analysis proves that complex sentence in SL has different structure with complex sentence in TL. It means that there is sentence structure shift in example number (1).

Sentence structure shift is also found in example number (2). The sentence in SL can be analyzed into sebelum matahari terbit (A), Pak Waluh (S), and berangkat (V). The element of (A) sebelum matahari terbit can be analysed again into matahari (S) and terbit (V). So, its structure is A (V) SV. This sentence belongs to complex sentence because it consists of two clauses. One clause and the others are joined by a conjunction.

The sentence in TL can be analyzed into before the sun rose (A), Mister Waluh $(\mathrm{S})$, went $(\mathrm{V})$, and away (A). The element of (A) before the sun rose can be described again into the sun (S) and rose (V). So, its structure is A (SV) S V A. This sentence belongs to complex sentence because one clause and the others are joined by a conjunction. This analysis shows us that complex sentence in SL has different structure with complex sentence in TL. It means there is sentence structure shift in example number (2).

In example number (3), the sentences in SL and in TL have the same elements, but they have different sequence of the elements. Clearly, sentence in SL can be analyzed into the exponent suatu hari (A), ketika ayahnya pergi lagi ke Gunung Agung (A), diam-diam (A), Manik Angkeran (S), mengikuti (V), and -nya (O). The element of (A) ketika ayahnya pergi lagi ke kaki Gunung Agung can be analyzed again into ayahnya (S), pergi (V), lagi (A), and ke kaki Gunung A gung (A). So, its structure is AA (SVAA) A S V O. This sentence belongs to complex sentence because it consists of two clauses. One clause and the others are joined by a conjunction. Sentence in TL can be described into the exponent one day (A), when his father went again to the foot of Mount Agung (A), Manik Angkeran (S), followed $(\mathrm{V})$, him $(\mathrm{O})$, secretly $(\mathrm{A})$. The element of $(\mathrm{A})$ when his father went again to the foot of Mount Agung can be analyzed again into his father (S), went (V), again (A), to the foot of Mount Agung (A). So, its structure is AA (SVAA)-SVOA. This sentence belongs to complex sentence because it is formed by two clauses. One and the others are joined by a conjunction. Based on this analysis, it can be said that there is sentence structure shift in example number (3) is caused by the different element. 


\section{CONCLUSION}

Based on the analysis that has been done, the following conclusion can be made. Structure shift spoken in this paper is structure shift in Indonesian-English translation. The discussion covers the structure shift in phrase, clause, and sentence level.

Phrase level structure shift is found only in noun and adjective phrase. The shifts in noun phrase are: H PostM PostM into PreM PreM H, H PostM into PreM H, PreM H PostM PostM into PreM PreM PreM H. The shift in adjective phrase is found only one: PreM H into $\mathrm{H}$ Post $\mathrm{M}$. The structure shifts in clause level are: SC into SVC, SV into SVA, and SV into SVO.

Sentence level structure shifts occur from: simple sentence in SL into simple sentence in TL, simple sentence in SL into complex sentence in TL, complex sentence in SL into simple sentence in TL, and complex sentence in SL into complex sentence in TL. The shift from simple sentence in SL into simple sentence in TL and the shift from complex sentence in SL into complex sentence in TL are caused by the different elements and the different sequence of elements carried by two different sentences both SL and TL.

\section{REFERENCES}

Aisyah, S. (2015). The Shift and Equivalence in the English Translation from Indonesian Noun Phrases in the Poem "Pantun Terang Buln di Midwest" by Taufik Ismail. State Islamic University Syarif Hidaya tullah.

Catford, J. C. (1965). A Linguistic Theory of Translation. Oxford: Oxford University Press.

Haryadi, A. E. (2001). Nyi Bungsu Rangrang. Jakarta: PT Gramedia.

Haryadi, A. E. (2002). A sal Mula Selat Bali (The Histories of Bali Strait). Jakarta: PT Gramedia.

Herman. (2017). Shift in Translation from English into Indonesia on Narrative Text. International Journal of European Studies, 1(3), 72-77.

Larson, M. L. (1984). Meaning-Based Translation. Maryland: University Press of America.

Leech, G. (1986). English Grammar for Today. London: Macillan Education Ltd.

Margono. (1999). Theory and Practice of Translation. Denpasar: Fakultas Sastra Universitas Udayana.

Nababan, R. (2008). Teori Menerjemah. Yogyakarta: Pustaka Pelajar.

Oeban, B. (2001). Kekuwo dan Kekele (Kekuwo and Kekele). Jakarta: PT Gramedia.

Quirk, R. (1973). A University Grammar of English. London: Longman Group Limited.

Ramlan, M. (1982). Sintaksis. Yogyakarta: CV Karyono.

Sakri, A. (1985). Ihwal Menerjemahkan. Bandung: ITB.

Singo, D. (2001). Dongeng Danau Toba (The Legend of Lake Toba). Jakarta: PT Gramedia. 